\title{
Nuevas DE Indias
}

\section{RESEÑA}

Gregorio Salinero, La trahison de Cortés. Désobéissances, procès politiques et gouvernement des Indes de Castille, seconde moitié du xvie siècle. París, Presses Universitaires de France, 2014, 375 páginas.

DOI: http://dx.doi.org/10.5565/rev/nueind.13

\section{Bernat HeRnÁndeZ} (Universitat Autònoma de Barcelona)

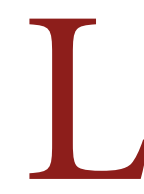

a trayectoria de Gregorio Salinero se ha caracterizado por una permanente confrontación de su trabajo con la documentación primaria colonial y con el difícil acervo notarial, que le ha llevado a aportaciones sustanciales en las temáticas de las movilidades y redes sociales en el mundo atlántico moderno, pero también a avances metodológicos destacados como los relativos a la historia de las listas o de antroponimia. Obras como la propia Une ville entre deux Mondes. Trujillo d'Espagne et les Indes au Xvie siècle. Pour une histoire de la mobilité à l'époque moderne (Madrid, 2006); o ediciones compartidas como los volúmenes Mezclado y sospechoso. Movilidad e identidades, España y América, siglos XVI-XVIII (Madrid, 2005), Un juego de engaños. Nombres, apellidos y movilidad en los siglos XV al XVIII (Madrid, 2010) y L'Italia dei cognomi. L'onomastica italiana nel contesto mediterraneo (Pisa, 2012), son un buen reflejo de todo ello.

Sus inquietudes profesionales y el acopio de información de primera mano que deriva en conclusiones siempre originales vuelve a ponerse de relieve en este libro que reseñamos, dedicado al estudio de la rebelión de Martín Cortés en la Nueva España de 1565 y a otros fenómenos de revuelta contemporáneos. No hay síntesis de bibliografía previa ni estados de la cuestión más o menos trillados, sino planteamientos muy nuevos. El análisis de la traición del hijo de Hernán Cortés, en este 
caso, es la excusa para exponer el panorama complejo de las relaciones sociales y políticas en las Indias de toda la segunda mitad del siglo XVI, porque el autor se remonta como antecedente a la convulsa década de 1540 y porque pone todo su esfuerzo en que el historiador establezca un marco comparativo con la situación en el virreinato peruano.

La introducción hace gala del excelente estilo en que está redactada la obra. Gregorio Salinero no opta por una presentación de contexto al uso, sino que antepone al lector las cuestiones arduas del léxico, los conceptos y las prácticas jurídicas que van a estar presentes en las siguientes páginas. Sin duda, son de interés notable para los estudiosos de la literatura y la filología las consideraciones que se hacen sobre terminología, abordada simultáneamente desde la exactitud rigurosa de las instancias judiciales y desde la perspectiva de la cultura popular de los rebeldes («Métaphores et noms d'oiseaux»), para reconstruir una «economía judicial» de la época y de los protagonistas: rebeldes, confederados, conspiradores, en sus diversas apelaciones.

La primera parte del libro («Les hommes de mal parti») aborda una serie de vidas, de lo que podrían traducirse «hombres de mala corte», de carácter excepcional por sus accidentadas biografías, pero que son también un espléndido reflejo de las tensiones vividas en el mundo de las Indias inmediatamente posterior a la conquista. La historia judicial de Bernardino Maldonado y su relación con los rebeldes de Taxco (Luis Roldán, Benito Castilla, Bernardino Venegas y Juan de Haro, detenidos por los auditores de la Audiencia de México en agosto de 1550), permite conocer las fórmulas de relación y clientelas formales e informales que explicaron muchas de las posiciones de alianza y conflicto en la sociedad novohispana. Relaciones más o menos densas que no sólo se dieron o alcanzaron en el mundo urbano sino también en unas redes más amplias que se extendieron hasta los confines; para la ocasión, estudiados desde el territorio septentrional de la Gran Chichimeca. En esta sociedad tan afectada por movilidades económicas y de estatus fueron estableciéndose núcleos de autonomía política que dificilmente pudieron ser controlados íntegramente por la Monarquía, o por quienes representaron el poder de la Corona en Indias. Desde la perspectiva de gran parte de la gente de Indias, la Monarquía no sólo estaba ausente de la dirección 
del orden social sino que su administración era claramente negligente, por cuanto no daba cobertura a lo que se consideraban reclamaciones de justicia o retribuciones de méritos desde el Nuevo Mundo.

«Le laboratoire de la Monarchie», la segunda parte, supone un cambio de enfoque territorial para Salinero, aunque el entramado teórico es el mismo. Se estudia la que historiográficamente ha sido la «rébellion modèle» de los antiguos conquistadores y nuevos encomenderos ante el ejercicio de poder de la Corona: la rebelión de los Pizarro en el virreinato del Perú. Un arquetipo de revuelta que también configuró un modelo de represión, conducida por La Gasca. Salinero entra en cuestiones interesantes en cuanto a la divulgación de las doctrinas de los insurgentes, así como la tradición política en la que intentaron insertar sus aspiraciones. El título de la parte tercera («Les répliques de la désobéissance») juega con la referencia ambivalente al carácter sísmico de la rebelión, por tanto de transformación estructural en lo político, como del efecto de imitación y de retroalimentación que los acontecimientos peruanos tuvieron sobre otros espacios territoriales y sociales del mundo de Indias.

Finalmente, en el apartado cuarto, dedicado a "La trahison de Cortés», se presentan los orígenes del movimiento insurreccional de 1565-1566 en la Nueva España. Es meritorio el trabajo de casi transcripción de los acontecimientos mediante el testimonio de sus protagonistas. No sólo porque se profundiza en los motivos personales y colectivos de un descrédito de la obra de la Corona en Indias, sino porque se amplia el campo de análisis histórico hacia manifestaciones de mentalidades. La confesión judicial va a la par de la confesión espiritual, de tal manera que las faltas de pecado y penitencia, con sus diferentes variables de punición, permiten entrar en las biografías de los conspiradores, quienes lo fueron solamente a ojos del poder metropolitano que no supo ni pudo imponerse en el Nuevo Mundo. Estos epígrafes se completan con los esquemas que figuran en el anexo, que nos representan gráficamente las redes de voluntades implicadas en el complot de Martín Cortés o de Alonso de Ávila en 1566, así como un impagable diagrama sobre las etapas de procedimientos judiciales ante crímenes de rebelión, que ilustran los dispositivos de castigo arbitrados por la Monarquía Hispánica en Indias. 
La noción de «frontera» es un motivo idóneo de reflexiones para Gregorio Salinero en el apartado de conclusiones. Concepto no aprehendido como geográfico o espacial, sino sobre todo como definidor del margen de actuación o de capacidades de maniobra del gobierno criollo e imperial, así como de diferencias de legitimidades. La frontera entre lo legal y lo ilegal cambió según las fluctuaciones de las hegemonías de confederados y rebeldes. A la postre, los convulsos espacios americanos de la segunda mitad del siglo Xvi nos dejaron espacios interpretativos de horizontes muy abiertos. Ni revueltas de criollos contra españoles, ni revueltas de las élites, ni coincidencias ni diferencias radicales en las circunstancias novohispanas o peruanas. Este libro de Gregorio Salinero marca, sin duda, época y esperemos que pronto esté disponible en español. Por ahora, en su versión francesa, con un útil índice de nombres, que reflejan el intenso trabajo documental sobre el Archivo Histórico Nacional, el Archivo General de Indias y sobre crónicas de época realizado por el autor, se convierte en un instrumento de trabajo primordial para aquellos investigadores que desde diferentes intereses se aproximan a la América colonial. 